\title{
INTERPRETASI MURTAD DALAM IBRANI 6: 1-8
}

\author{
Friska Gandaria, Yusuf L. M.
}

Sekolah Tinggi Teologi Injili Setia Siau

lmy38831@gmail.com

\begin{abstract}
The concept of Apostasy in Hebrews 6: 1-8 is often debated among Christian theologians. The text is considered an ongoing event for true Christians and people who do not truly believe in God. The text of verses 4-5 is supposed to show the criteria for a Christian who can apostatize again. Is this true? To understand this text, it is necessary to make an analysis with an exposition study approach to words, phrases, and clauses in the text while still paying attention to their historical grammar to get the correct meaning in the original context. Based on this

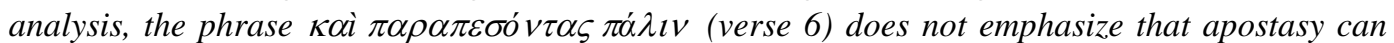
happen to true Christians or truly believe in God, but rather refers to Christians who do not really believe so that when they faced persecution during the Nero Emperor, many Christians left their faith. To that end, the writer to the Hebrews warns against the dangers of rejecting God in this situation. People who do not have true faith will surely apostatize or reject God and may not be renewed.
\end{abstract}

Keywords: Interpretation, Apostate, Hebrew 6: 1-8

\begin{abstract}
Abstrak. Konsep Murtad dalam Ibrani 6:1-8 sering menjadi perdebatan di kalangan teolog Kristen. Teks tersebut dianggap sebagai peristiwa yang sedang terjadi kepada orang Kristen sejati dan orang yang tidak sungguh-sungguh percaya Tuhan. Teks ayat 4-5 dianggap memperlihatkan kriteria orang Kristen yang bisa murtad lagi. Apakah benar demikian? Untuk memahami teks ini, penulis menganalisisnya dengan pendekatan studi eksposisi terhadap kata, frasa, dan klausa dalam teks dengan tetap memperhatikan gramatika historisnya untuk mendapatkan pengertian yang benar

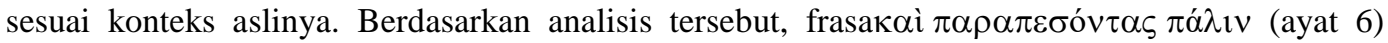
tidak menekankan murtad bisa terjadi terhadap orang Kristen sejati atau sungguh-sungguh percaya Tuhan, melainkan mengacu kepada orang Kristen yang tidak sungguh-sungguh percaya sehingga ketika menghadapi penganiayaan pada pada masa Kaisar Nero maka banyak orang Kristen yang meninggalkan imannya. Untuk itu, penulis surat Ibrani memberi peringatan keras akan bahaya menolak Tuhan dalam situasi tersebut. Orang yang tidak beriman sungguh-sungguh pasti akan murtad atau menolak Tuhan dan tidak mungkin dibaharui lagi.
\end{abstract}

Kata-kata kunci: Interpretasi, Murtad, Ibrani 6:1-8

\section{PENDAHULUAN}

Salah satu konsep yang sering menjadi bahan perdebatan di kalangan teolog Kristen adalah ajaran tentang murtad. Pertanyaan umum yang sering 
BONAFIDE: Jurnal Teologi dan Pendidikan Kristen

www.jurnal.sttissiau.ac.id/Volume 1/Nomor 2/Desember 2020/hal. 234-257

diajukan adalah apakah orang Kristen bisa murtad? Faktanya dalam kehidupan sehari-hari memang ada orang Kristen yang murtad, mulai dari kaum awam hingga pelayan Tuhan. Dalam Alkitab ada Yudas Iskariot yang telah hidup bersama-sama dengan Yesus namun bisa murtad. (Junimen 2012) Hal ini jelas memperlihatkan polemik pemahaman konsep murtad yang bersifat pro dan kontra di dalam kehidupan umat kristiani.

Sebagian besar gereja memahami bahwa murtad itu memang benar-benar bisa terjadi di kalangan orang percaya. Hal itu didasarkan pada pemahaman terhadap Ibrani 6:1-8, khususnya ayat 4-6. Dalam teks ini beberapa kata kerja secara gamblang memperlihatkan bahwa murtad bisa terjadi bagi orang percaya dengan menolak Kristus di kemudian hari dan tidak mungkin dibaharui lagi karena dianggap telah menghina Allah.

Secara historis, kehidupan para pembaca dalam konteks surat Ibrani tengah berada di dalam bahaya penganiayaan di bawah pemerintahan kekaisaran Romawi yang dijabat oleh kaisar Nero. Saat itu mereka dituntut untuk menyembah kaisar sebagai Tuhan, suatu hal yang membuat orang-orang Kristen pada waktu itu merasa tertekan dan bahaya kemurtadan itu sudah di depan mata.(Evans 2000) Bagi yang tunduk menyembah kaisar berarti telah murtad dan meninggalkan imannya terhadap Kristus.

Namun pertanyaan yang sangat penting dan menarik untuk dijawab adalah bagaimana konsep murtad dalam Ibrani 6:1-8? Apa maksud frasa kata kerja "pernah diterangi hatinya", pernah mengecap karunia sorgawi", "mendapat bagian 
BONAFIDE: Jurnal Teologi dan Pendidikan Kristen

www.jurnal.sttissiau.ac.id/Volume 1/Nomor 2/Desember 2020/hal. 234-257

dalam Roh Kudus"? Apakah orang dengan kriteria dalam frasa kata kerja di atas ketika murtad tidak bisa lagi dibaharui? Untuk menjawab pertanyaan seperti ini, maka dalam penelitian ini, penulis berupaya mengkaji konsep murtad dalam teks ini dengan memberi analisis pada kata, frasa ataupun klausa dalam ayat 4-5 dan secara khusus pada ayat 6 "namun yang murtad lagi, tidak mungkin dibaharui sekali lagi" dengan pendekatan analisis secara gramatika-historis dan menggunakan sumber-sumber buku primer yang membahas teks dan konteks ini guna mendapatkan arti dan maksud yang sebenarnya.

\section{METODE PENELITIAN}

Kajian penelitian ini mengacu kepada kajian literatur dengan metode pendekatan analisis eksposisi teks dan konteks.(Tubagus 2019) Kemudian memberikan deskripsi maksud teks dan konteks tanpa mengabaikan analisis gramatikal-historis disertai dengan tafsiran atas analisis gramatikal tersebut dengan menggunakan literatur yang berkaitan analisis konteks Ibrani 6:1-8. Dalam deskripsi tersebut penulis melakukan kajian terhadap kata dan frasa serta klausa di dalam teks untuk menemukan pengertian dan makna yang benar sesuai maksud penulis Kitab Suci dalam konteks aslinya.(Ndolu \& Tari, 2020) Untuk lebih memahami maksud teks ini, maka penulis tidak hanya menggunakan terjemahan LAI tetapi juga menggunakan terjemahan KJV dan NIV untuk melihat beberapa kata, frasa atau klausa dalam teks yang yang tidak terlalu jelas maksudnya dalam terjamahan LAI.(Kawangung et al. 2020) 
BONAFIDE: Jurnal Teologi dan Pendidikan Kristen

www.jurnal.sttissiau.ac.id/Volume 1/Nomor 2/Desember 2020/hal. 234-257

\section{HASIL PENELITIAN}

Hasil analisis eksposisi terhadap konsep murtad menurut Ibrani 6:1-8 adalah sebagai berikut. Analisis kata $\alpha \varphi \varepsilon ́ v \tau \varepsilon \varsigma$ pada ayat 1 dari akar kata dari kata kerja àøí $\mu \iota$ merupakan kata kerja artinya meninggalkan. Maksudnya tidak membahas lebih lanjut mengenai asas pengajaran itu bukan berarti tidak penting sebab kita mau maju lebih jauh dalam hal pertumbuhan iman. Asas pertama ajaran tentang Kristus adalah fondasi dan dari fondasi itulah konteks menekankan membangun dan maju pada tahapan iman yang lebih tinggi tanpa harus melupakan asas-asas tersebut seperti yang ditekankan dalam ayat 2 dan 3.

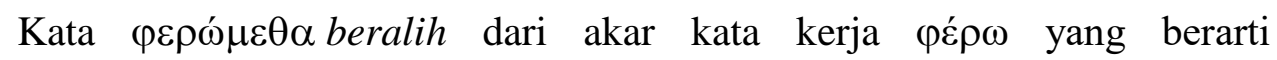
“membawa." Penekanan kata ini merupakan sebuah ajakan rohani artinya tidak hanya tinggal tetap melainkan adanya sebuah perubahan atau pergerakan iman menuju pada perkembangan yang penuh. Kata $\tau \varepsilon \lambda \varepsilon ı$ ó $\eta \tau \alpha$ ini penuh dalam teks ini bukan kesempurnaan tetapi lebih tepat diartikan sebagai "kedewasaan", yaitu kedewasaan rohani. Beralih kepada perkembangan yang penuh artinya semakin dewasa dalam pikiran dan perbuatan untuk mencapai kedewasaan iman. Jadi penerima surat Ibrani seharusnya sudah berada pada tahap ini, mengingat tekanan berat yang dihadapi saat itu dari Kekaisaran Romawi yang bisa membuat orang Kristen meninggalkan imannya atau murtad.

Konteks ayat 4 dan 5 dalam analisis menunjukkan kriteria orang Kristen zaman itu sebagai Kristen sejati karena telah menerima Injil dan mendapat bagian

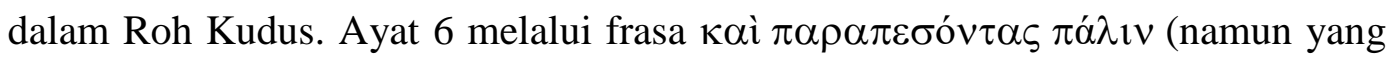


BONAFIDE: Jurnal Teologi dan Pendidikan Kristen

www.jurnal.sttissiau.ac.id/Volume 1/Nomor 2/Desember 2020/hal. 234-257

murtad lagi) harus dimengerti sebagai peringatan bahaya murtad yang dapat terjadi dalam kehidupan orang percaya. Secara historis, pembaca surat Ibrani pada waktu itu berada dalam ancaman penganiayaan. Karena itu mereka harus memiliki kedewasaan iman agar tidak ada yang murtad. Frasa

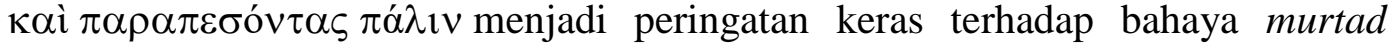
yang mengancam kehidupan mereka. Mereka diingatkan untuk waspada supaya jangan ada dari antara mereka murtad.

Penekanan murtad dalam konteks ini sebagai peringatan juga jelas dari struktur pembagian surat Ibrani. Pasal sebelum dan sesudahnya membahas mengenai keimaman Yesus namun pada pasal 6 ini seolah-olah terselip pembahasan mengenai bahaya murtad. Ini menunjukkan bahwa bahaya murtad ditekankan sebagai bentuk peringatan keras sehingga harus ada kedewasaan iman. Diperkuat juga dengan peralihan kata ganti orang pertama jamak "kita" (ayat1) menjadi orang ketiga jamak "mereka" (ayat 4). Tampaknya penulis surat Ibrani tidak mengidentifikasikan dirinya dan para pembaca suratnya sebagai orang yang murtad, namun mengingatkan bahwa orang Kristen yang tidak dewasa imannya pasti murtad ketika menghadapi penganiayaan. Jadi secara dogmatis jelas ditekankan bahwa tidak ada orang Kristen sejati yang dapat murtad sebab Roh Kudus adalah jaminan bagi mereka untuk tetap tekun memelihara iman, Roh Kudus menjadi arrabon bagi mereka. 
BONAFIDE: Jurnal Teologi dan Pendidikan Kristen

www.jurnal.sttissiau.ac.id/Volume 1/Nomor 2/Desember 2020/hal. 234-257

\section{PEMBAHASAN}

Pasal sebelumnya yaitu 5:11-14, penulis surat Ibrani menegaskan bahwa orang Ibrani yang sudah menerima Yesus dalam waktu yang cukup lama sudah seharusnya menjadi pengajar namun pada kenyataannya mereka belum memenuhi syarat untuk itu. Mereka belum mampu menerima ajaran yang keras, baru sebatas kebenaran dasar atau "susu"saja". Ia mengibaratkan mereka seperti anak kecil yang masih memerlukan susu saja sebab anak kecil tidak dapat mencerna makanan keras.(Pfeiffer dan Harrison 2013) Mereka belum dapat membedakan yang baik dan jahat. Mereka bahkan tidak memiliki pemahaman akan kebenaran tetapi juga tidak berpengalaman dengan kebenaran.(Porter 2007) Dengan demikian mereka berada dalam bahaya berbalik dari iman yang menghidupkan kepada iman yang mematikan. Mereka bias meninggalkan kepercayaan kepada Kristus dan kembali kepada ajaran Yudaisme yang begitu mempengaruhi mereka.

Karena kondisi inilah teks Ibrani 6:1-8 ditulis untuk memperingatkan pembaca maju pada kedewasaan rohani. Mereka tidak bisa hanya berhenti pada pemahaman prinsip dasar mengenai Kristus, tetapi perlu maju pada pertumbuhan rohani yang sempurna. Ketidaksediaan untuk bertumbuh adalah kemunduran iman yang ujungnya adalah kemurtadan. Ibrani 6:1-8 merupakan kesinambungan dari bagian sebelumnya (5:11-140, yang merupakan satu kesatuan sebagai sebuah peringatan terhadap bahaya kemurtadan.

Ayat 1 "marilah kita tinggalkan asas-asas pertama dari ajaran tentang

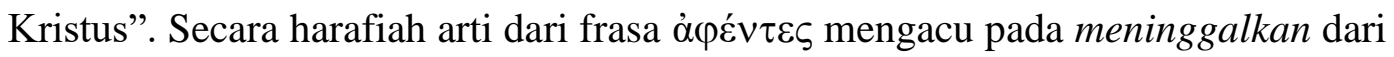


BONAFIDE: Jurnal Teologi dan Pendidikan Kristen

www.jurnal.sttissiau.ac.id/Volume 1/Nomor 2/Desember 2020/hal. 234-257

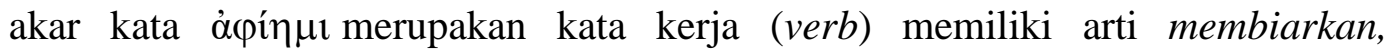

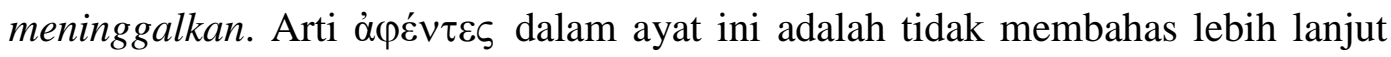
(bukan dalam arti hal ini tidak penting), sebab kita mau maju lebih jauh (Drewes 2006). Bukan berarti mereka tidak memerlukan lagi asas-asas pertama ajaran tentang Kristus. Ajaran tersebut adalah dasar (fondasi), dan dari fondasi itulah mereka harus membangun dan maju pada tahapan iman yang lebih tinggi.

Frasa $\tau \tilde{\eta} \varsigma \dot{\alpha} \rho \chi \tilde{\eta} \varsigma$ “asas-asas” pertama dari ajaran tentang Kristus menunjuk pada tahap pemahaman yang paling elementer tentang Kristus (Darmaputera 2014) yaitu pelbagai pembaptisan, penumpangan tangan, kebangkitan orang-orang mati dan hukuman kekal (ayat 2). (Henry 2016)

Pembaca surat Ibrani seharusnya sudah bertumbuh, tidak hanya berkutat pada ajaran-ajaran dasar ini. Seperti dikatakan Calvin,

As the builder must begin with the foundation, so must he go on with his work that the house may be built. Similar is the case as to Christianity; we have the first principles as the foundation, but the higher doctrine ought immediately to follow which is to complete the building (Calvin 1853, 92)

Orang Kristen harus memiliki asas-asas pertama sebagai landasan, tetapi ajaran yang lebih tinggi harus segera diikuti untuk menyelesaikan pembangunan iman. Seperti halnya seorang guru tidak akan mencapai kesuksesan jika setiap kali mulai mengajar ia harus meletakan dasar-dasar saja.(Barclay 2011)

Selanjutnya frasa "beralih kepada perkembangannya yang penuh" . Kata

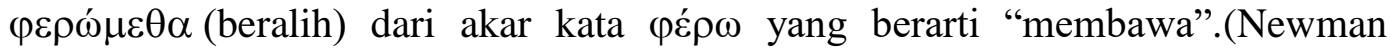
2011) Perlu diperhatikan bahwa kata $\varphi \varepsilon \rho \omega ́ \mu \varepsilon \theta \alpha$ merupakan kata kerja berbentuk present - subjunctive - passive; dibawa dan ditambah dengan ̇ं $\pi$ (preposition); 
BONAFIDE: Jurnal Teologi dan Pendidikan Kristen

www.jurnal.sttissiau.ac.id/Volume 1/Nomor 2/Desember 2020/hal. 234-257

kepada, maka secara harafiah diterjemahkan menjadi dibawa kepada dan oleh TB diterjemahkan menjadi beralih kepada sementara dalam terjemahan KJV dan NIV diterjemahkan menjadi go "pergi". Namun perbedaan ini bukanlah sebuah pertentangan karena maknanya saling berkaitan yaitu beralih, pergi, dibawa semua itu merujuk pada langkah menuju tahap selanjutnya. Tetapi menurut penulis makna kata ini yang lebih sesuai dengan konteks adalah beralih. Hal ini merupakan sebuah ajakan rohani melakukan perubahan menuju perkembangan yang penuh. Namun, bentuk pasif dari kata $\varphi \varepsilon \rho \omega ́ \mu \varepsilon \theta \alpha$ ini menunjukan bahwa hal ini bukan berbicara mengenai usaha pribadi dari seseorang melainkan penyerahan diri kepada suatu pengaruh yang aktif (Stibbs 2012), yaitu kuasa Allah (bnd. Ayat 3) (Tubagus 2020). Pertumbuhan ini menuju ke kepada $\tau \varepsilon \lambda \varepsilon \iota$ $\tau \eta \tau \alpha$ (perkembangan yang penuh) yang tampaknya lebih cocok diterjemahkan dengan "kedewasaan" secara rohani. Jadi beralih kepada perkembangan yang penuh artinya menuju kepada tingkat kedewasaan baik dalam pikiran maupun dalam perbuatan untuk mencapai kedewasaan iman sehingga iman orang Kristen tidak akan gampang tergoyahkan.

Selanjutnya adalah ayat 4-6. Ayat ini sering dijadikan dasar anggapan bahwa orang Kristen sejati bisa murtad. Berbeda dengan ayat 1-3 yang menggunakan kata kerja bentuk orang pertama jamak "kita", bagian ini memakai kata kerja dalam bentuk orang ketiga jamak "mereka". Ini menegaskan bahwa penulis Ibrani tidak mengidentifikasikan dirinya dan para pembaca suratnya 
BONAFIDE: Jurnal Teologi dan Pendidikan Kristen

www.jurnal.sttissiau.ac.id/Volume 1/Nomor 2/Desember 2020/hal. 234-257

dengan orang-orang yang digambarkan dalam ayat 4-6 dalam teks ini. Intinya, mereka bukanlah orang yang telah murtad.

\section{Kata $\phi \omega \tau 1 \sigma \theta \dot{\varepsilon} v \tau \alpha \varsigma$}

Menurut Henry, kata $\phi \omega \tau \imath \sigma \theta \varepsilon ́ v \tau \alpha \varsigma$ “yang pernah diterangi hatinya” lebih tepat dipahami sebagai pengetahuan yang berupa gagasan dan pencerahan umum yang bisa saja dimiliki orang secara berlimpah (Henry 2016). Namun gagasan ini masih bersifat abstrak. Archer menyatakan $\phi \omega \tau 1 \sigma \theta \varepsilon \dot{v} \tau \alpha \varsigma$ "yang pernah diterangi hatinya"adalah orang yang mengalami pencerahan melalui pengajaran yang jelas mengenai Injil (dalam Situmorang 2015). Makna “penerangan” di sini menunjuk pada pengajaran, lebih sesuai dengan konteks surat Ibrani jika diperhatikan dalam 10:26 "sesudah memperoleh pengetahuan tentang kebenaran" sama artinya dengan sesudah memperoleh pengajaran tentang injil. Dengan demikian dapat disimpulkan bahwa“orang yang pernah diterangi hatinya" adalah orang yang kepada mereka telah diberi pencerahan atau telah menerima pengajaran tentang Injil dan sudah mengetahui kebenaran tentang Kristus.

\section{Frasa "mengecap karunia sorgawi"}

Mereka yang mengecap karunia sorgawi adalah mereka yang merasakan pekerjaan baik dari Roh Kudus yang bekerja dalam jiwa mereka. Hal ini dipertegas oleh Barclay bahwa, frasa "mengecap karunia sorgawi”adalah orang Kristen yang telah menikmati pemberian sorgawi yang gratis yaitu pengampunan di dalam Kristus yang tidak akan bisa didapat melalui usaha manusia sendiri (Barclay 2011). 
BONAFIDE: Jurnal Teologi dan Pendidikan Kristen

www.jurnal.sttissiau.ac.id/Volume 1/Nomor 2/Desember 2020/hal. 234-257

\section{Frasa "mendapat bagian dalam Roh Kudus".}

Maksud frasa "mendapat bagian dalam Roh Kudus" menunjuk pada mereka yang mendapat bagian dalam karunia-karunia-Nya yang luar biasa dan ajaib seperti mengusir setan dalam nama Kristus dan melakukan banyak pekerjaan lain (Henry 2016). Orang yang demikian mempunyai pedoman dan kekuatan baru dalam hidupnya yang dapat memberitahunya apa yang harus diperbuat dan yang memampukannya untuk melakukannya. Itu merupakan bagian dari karya Roh Kudus.

\section{Frasa "yang mengecap firman yang baik dari Allah"}

Menurut Archer, mengecap firman yang baik dari Allah artinya telah memahami secara jelas pesan dari Alkitab dari segi mental maupun intelektual. Barclay menambahkan argumennya bahwa orang Kristen yang telah menikmati firman Allah adalah orang Kristen yang telah menemukan kebenaran (Barclay 2011). Pernyataan ini benar karena Firman Allah adalah seratus persen kebenaran yang pasti. Jadi frasa "yang mengecap firman yang baik dari Allah" menunjuk pada orang-orang yang telah menerima pengajaran firman dengan benar.

\section{Frasa "mengecap karunia-karunia dunia yang akan datang"}

Henry berpendapat bahwa frasa ini menunjuk pada mereka yang mungkin mendapat kesan-kesan kuat mengenai sorga. Orang yang demikian adalah orang yang sekarang sedang merasakan berkat zaman milik Allah bahkan sedang mencicipi kebahagiaan zaman yang kekal itu (Barclay 2011). Artinya mereka yang sekarang telah merasakan hadirnya kerajaan Allah dalam kehidupan mereka. 
BONAFIDE: Jurnal Teologi dan Pendidikan Kristen

www.jurnal.sttissiau.ac.id/Volume 1/Nomor 2/Desember 2020/hal. 234-257

Mereka merasakan kuasa Allah yang memerintah atas mereka. Tanda-tanda

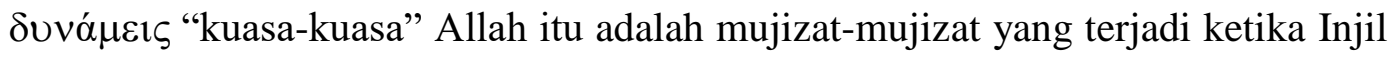
diberitakan dan ketika mereka menerima injil itu, karena pada zaman rasuli pemberitaan Injil disertai dengan mujizat-mujizat dan tanda-tanda yang ajaib.

Jadi keempat bagian di atas dapat disimpulkan bahwa semua itu menunjuk pada kriteria orang-orang Kristen yang telah mengetahui kebenaran tentang Kristus, telah memiliki Roh Kudus dalam hati. Mereka adalah orang-orang percaya yang telah mengenal Yesus sebagai Juruselamat. Akan tetapi, frasa

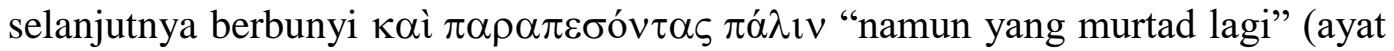
6). Pertanyaannya, apakah mereka yang dengan kriteria di atas bisa murtad? Bagaimana mungkin orang yang telah mengambil bagian dalam Roh Kudus dapat murtad lagi?

Jika diperhatikan perbandingan terjemahannya, kata Yunani di awal ayat ini yakni אaì (dan) memiliki penekanan yang sama dengan yang diterjemahkan oleh KJV dengan kata and sedangkan NIV memiliki penekanan yang berbeda diterjemahkan dengan if, lebih berbeda lagi penekanan yang diterjemahkan dalam TB dengan kata namun. Hal ini menunjukan bahwa terjemahan KJV lebih sesuai dengan bahasa aslinya karena memiliki makna yang sama. Selanjutnya diperhatikan istilah murtad. Istilah $\pi \alpha \rho \alpha \pi \varepsilon \sigma o ́ v \tau \alpha \varsigma$ "murtad" adalah suatu penolakan yang sempurna dan pencabutan iman kepada Kristus (Tim Penyusun 2012). Kata $\pi \alpha \rho \alpha \pi \varepsilon \sigma o ́ v \tau \alpha \varsigma$ (aorist-participle-active-accusative-masculineplural) merupakan kata kerja dari akar kata $\pi \alpha \rho \alpha \pi i ́ \tau \tau \omega$ (kata benda: $\pi \alpha \rho \alpha ́ \pi \omega \mu \alpha$ 
BONAFIDE: Jurnal Teologi dan Pendidikan Kristen

www.jurnal.sttissiau.ac.id/Volume 1/Nomor 2/Desember 2020/hal. 234-257

"kesalahan", “pelanggaran”) yang berarti “melakukan kesalahan” atau "menjadi sesat” yang oleh NIV dan KJV diterjemahkan dengan kata fall "jatuh.” Arti jatuh sini adalah jatuh ke dalam dosa. Hal ini lebih diperjelas lagi oleh terjemahan TB dengan kata "murtad". Hal ini tidak ada perbedaan penekanan makna dari terjemahan di atas sekalipun penggunaan kata yang berbeda tetapi makna yang terkandung dalam terjemahan-terjemahan tersebut menunjuk pada suatu kesalahan

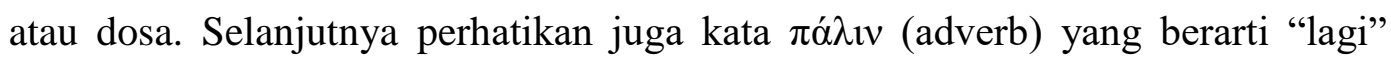
menunjuk pada sesuatu yang pernah dilakukan (Mounce 2011). Jadi secara

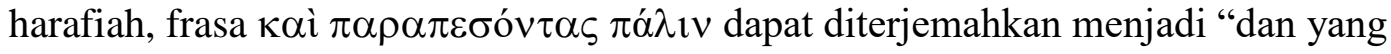
menjadi sesat lagi” menunjuk kepada mereka yang telah sesat yang kembali jatuh dalam kesalahan atau dosa yang secara jelas menunjuk pada kemurtadan.

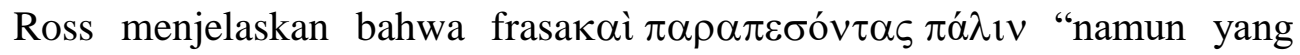
murtad lagi” bisa diterjemahkan menjadi “jika mereka murtad” (Newman 2011). Di sini Ross menerjemahkan sesuai terjemahan NIV. Dalam hal ini penulis surat mengingatkan bahwa seorang yang tidak mau bersedia bertumbuh di dalam kehidupan Kristen berarti suatu kemunduran dan akan berujung pada murtad. Murtad dalam perikop ini berarti hanya mencari keuntungan secara lahiriah tanpa didasari kesungguhan dalam mengiring Tuhan (Situmorang 2015). Jadi murtad itu terjadi pada orang-orang yang tidak sungguh-sungguh bertobat (pertobatan palsu).

Barclay mengartikan istilah $\pi \alpha \rho \alpha \pi \varepsilon \sigma o ́ v \tau \alpha \varsigma$ "murtad" sebagai pengingkaran iman karena perikop ini ditulis pada zaman penganiayaan (Barclay 2011). Sungguh dilema bagi pengikut Kristus. Jika akan tetap mempertahankan 
BONAFIDE: Jurnal Teologi dan Pendidikan Kristen

www.jurnal.sttissiau.ac.id/Volume 1/Nomor 2/Desember 2020/hal. 234-257

imannya, hidupnya akan terancam, susah mencari pekerjaan, dan sewaktu-waktu siap menghadapi aniaya yang sampai membawa kepada kematian. Bila menyangkal Kristus, hidupnya terjamin secara lahiriah tetapi ia akan dibenci dan dikucilkan oleh pengikut Kristus yang setia. Orang yang seperti itulah yang dianggap sebagai orang murtad (Situmorang 2015). Pengingkaran iman kepada Kristus berarti menganggap hidup dan kenikmatan diri sendiri lebih berharga ketimbang Yesus Kristus (Barclay 2011).

Penulis surat mengingatkan orang-orang Kristen tentang bahaya kemurtadan yang bisa saja mengancam iman mereka karena latar belakang penganiayaan kekaisaran Romawi pada waktu itu (Evans 2000). Ayat ini dianggap sebagai peringatan bagi orang-orang percaya untuk tidak murtad. Secara manusia dapat dikatakan seseorang bisa untuk murtad, akan tetapi tidaklah mungkin bagi Allah untuk gagal dalam memelihara umat-Nya (Sproul 2000). Calvin menegaskan bahwa,

Orang-orang Kristen masih mungkin jatuh dalam dosa dan ada yang mengalami kemunduran iman yang sangat besar tetapi bila ia sungguh telah dilahirkan kembali, bila Roh Kudus sungguh ada di dalam dia, membuat dia menjadi percaya, maka Roh Kudus merupakan jaminan dari bagian yang nanti akan diterimanya secara penuh.(dalam Palmer 2013, 115)

Hal ini memberi arti bahwa orang Kristen mungkin saja mengalami kekalahan sementara oleh dosa, tetapi dosa tidak akan pernah dapat menguasainya lagi. Selalu ada perjuangan melawan dosa karena Allah tidak mengambil Roh Kudusnya dari orang-orang percaya (Palmer 2013). Untuk itu, istilah murtad dalam teks ini ditegaskan sebagai sebuah peringatan keras bagi orang Kristen 
BONAFIDE: Jurnal Teologi dan Pendidikan Kristen

www.jurnal.sttissiau.ac.id/Volume 1/Nomor 2/Desember 2020/hal. 234-257

supaya memiliki fondasi iman yang kokoh sebab banyak orang yang mengaku percaya tetapi meinggalkan imannya ketika menghadapi penganiyaan. Jika percaya sungguh-sungguh, jelas tidak meninggalkan imannya walaupun menghadapi penganiyaan. Penekanan peringatan ini juga diperkuat melalui struktur pemaparan surat Ibrani di mana pada pasal-pasal sebelumnya yakni pasal 3 sampai pasal 5 dan dilanjutkan lagi pada pasal 7 sampai pasal 9 di situ membahas mengenai keimaman Yesus. Namun di pasal 6 tiba-tiba terselip perikop mengenai bahaya kemurtadan. Hal ini menunjukan bahwa konsep murtad dalam ayat ini sebuah bentuk peringatan akan bahaya menolak Kristus diselipkan penulis surat Ibrani kepada para pembaca pada waktu itu. Ditambah lagi dengan peralihan kata ganti orang pertama jamak (ayat 1) menjadi orang ketiga jamak (ayat 4) yang digunakan oleh penulis surat Ibrani menunjukan bahwa penulis surat Ibrani ingin menyatakan bahwa baik penulis maupun pembaca yang sungguhsungguh percaya Tuhan bukanlah orang-orang yang murtad. Hanya saja penulis surat Ibrani tidak dapat membedakan mana orang-orang pilihan Allah dan mana yang bukan pilihan Allah di antara para pembaca suratnya sehingga ia memberikan sebuah peringatan keras supaya mereka bertekun dalam iman, sebab bahaya murtad dapat terjadi di antara para pembaca yang tidak sungguh-sungguh percaya karena situasi dan kondisi yang sedang terjadi pada waktu itu yakni penganiayaan sudah di depan mata. Olehnya penulis surat Ibrani memperingatkan para pembaca suratnya untuk mempertahankan iman kepada Allah supaya panggilan Allah atas mereka sebagai kaum pilihan Allah semakin diteguhkan 
BONAFIDE: Jurnal Teologi dan Pendidikan Kristen

www.jurnal.sttissiau.ac.id/Volume 1/Nomor 2/Desember 2020/hal. 234-257

sehingga ketika terjadi penganiayaan dan situasi sulit yang mengancam iman, mereka tidak meniggalkan imannya kepada Kristus.

Luther menyebut hal ini sebagai "pemberian dorongan dan nasehat yang injili”(Palmer 2013, 113). Ini mengingatkan akan tanggung jawab orang percaya untuk bertekun dalam perjalanan iman bersama Allah. Di sini perlu kembali melihat latar belakang konteks dalam surat Ibrani. Tampaknya peringatan yang dalam konteks ini merupakan peringatan kepada orang Kristen Yahudi untuk berdiri bersama dengan gereja yang dianiaya dan tidak kembali kepada Yudaisme (Morris 2006). Peringatan yang penulis surat Ibrani nyatakan dalam ayat ini merupakan sebuah peringatan keras karena perlu diperhatikan bahwa kemurtadan adalah hal yang benar-benar nyata dan dapat terjadi dalam kehidupan orang Kristen yang tidak sungguh-sungguh hidup dalam Tuhan. Kriteria-kriteria orangorang yang murtad dalam ayat 4-5 bisa menunjuk kepada orang yang tidak sungguh-sungguh percaya Tuhan.

Hal ini memberi arti bahwa tidak semua orang Kristen telah lahir baru. Ada orang lain yang terlihat seperti malaikat terang, tetapi sebenarnya adalah hamba Iblis (Palmer 2013). Contoh lain lagi seperti Yudas, dapat mengabarkan Injil dan mengadakan mujizat, tetapi tidak beroleh keselamatan. Hal ini tidak memberi arti bahwa ada orang percaya yang murtad melainkan kemurtadan itu adalah suatu hal yang nyata namun hanya berlaku bagi orang-orang yang tidak sepenuhnya hidup dalam Tuhan yang digolongkan sebagai orang-orang bukan kaum pilihan Allah seperti yang tertulis dalam Roma 9:6 "tidak semua orang yang 
BONAFIDE: Jurnal Teologi dan Pendidikan Kristen

www.jurnal.sttissiau.ac.id/Volume 1/Nomor 2/Desember 2020/hal. 234-257

berasal dari Israel adalah orang Israel". Calvin memberi arti dari pernyataan di atas bahwa, "tidak semua orang yang menjadi anggota gereja sungguh-sungguh menjadi milik anggota gereja yang benar"(Sproul 2000, 181).

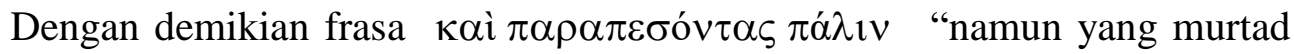
lagi" tidak berarti bahwa ada orang percaya atau Kristen sejati yang murtad. Kristen sejati tidak mungkin murtad karena Allah telah menjamin Roh Kudus untuk memelihara iman sekalipun mengalami pengunduran iman namun akan kembali percaya kepada Allah sehingga semakin jelas pernyataan yang mengatakan "sekali diselamatkan tetap diselamatkan". Frasa ini merupakan sebuah peringatan terhadap bahaya kemurtadan yang secara nyata bisa terjadi dalam kehidupan para pembaca surat ini sehingga mereka diingatkan untuk waspada supaya jangan ada dari antara mereka yang hatinya jahat yakni orangorang yang mengaku Kristen, yang secara lahiriah menampakkan kepercayaan mereka namun sebenarnya memang belum dilahirkan kembali dan tidak sepenuhnya hidup dalam Tuhan. Dengan peringatan ini akan membuat para pembaca bersungguh-sungguh hidup dalam Tuhan sehingga panggilan dan pilihan Tuhan atas mereka semakin teguh (Morris 2006).

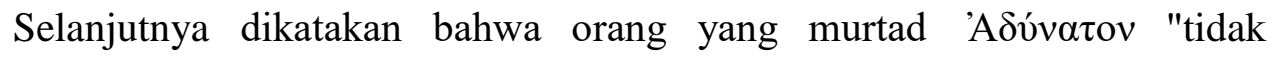
mungkin"dibaharui sekali lagi. Ini merupakan akibat dari kemurtadan itu. F. F. Bruce menyatakan bahwa, "is possible for human beings to arrive at a state of heart and life where they can no longer repent" (Stedman 1992, 24). Artinya mungkin bagi manusia untuk tiba pada keadaan hati dan kehidupan di mana 
BONAFIDE: Jurnal Teologi dan Pendidikan Kristen

www.jurnal.sttissiau.ac.id/Volume 1/Nomor 2/Desember 2020/hal. 234-257

mereka tidak bisa lagi bertobat. Hal ini menunjuk pada kemurtadan bagi orangorang yang tidak benar-benar hidup dalam Tuhan. Kemurtadan tersebut tidak mungkin digolongkan sebagai dosa biasa sebab di dalamnya mencakup penolakan terhadap yang disediakan Allah di dalam Kristus. Kemurtadan dapat dikatakan sebagai "dosa yang tidak terampuni”. Karenanya, harapan untuk bisa dibaharui kembali menjadi lenyap. Mustahil memperbaharui mereka sekali lagi hingga mereka bertobat (Henry 2016).

Perhatikan kataAdúvatov (adjective-nominative-neuter-singular) dari akar

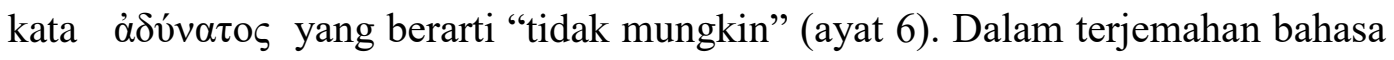

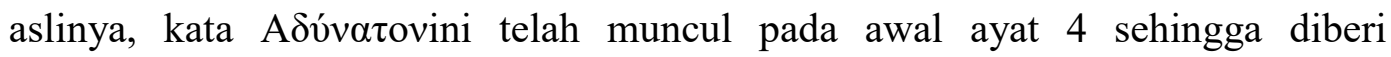
penekanan "tidak mungkin orang yang digambarkan dalam ayat 4-5 dan yang

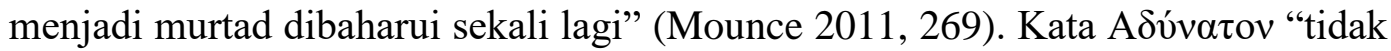
mungkin" di sini bisa saja tidak berlaku bagi kaum pilihan untuk murtad dan bisa juga maksud penulis surat Ibrani bahwa adalah mustahil untuk memperbaharui orang yang menolak Kristus.

Frank Stagg menyatakan pendapatnya bahwa pembaharuan (anakainizein) atau regenerasi adalah milik Allah sendiri. Henry menambahkan bahwa "Allah dapat memperbarui mereka untuk bertobat namun sangat jarang hal itu dilakukan" (Henry 2016, 100). Pernyataan ini seolah-olah menegaskan bahwa Allah masih mungkin memperbarui orang-orang yang murtad untuk bertobat karena tidak ada yang mustahil bagi Allah. Akan tetapi jika dilihat dari konteks ayat ini, pembaruan itu tidak mungkin juga bagi Allah. Allah tidak mungkin membaharui 
BONAFIDE: Jurnal Teologi dan Pendidikan Kristen

www.jurnal.sttissiau.ac.id/Volume 1/Nomor 2/Desember 2020/hal. 234-257

orang yang menolak Kristus dengan sengaja. Senada dengan itu, Robert juga menyatakan bahwa "sebab Allah tidak memiliki jalan yang lain jika kalvari sudah ditolak"(Pfeiffer dan Harrison 2013, 1227). Hal ini menunjukan bahwa korban Kristus adalah satu-satunya jalan yang sempurna untuk keselamatan sesuai yang tertulis dalam Ibrani 10:26-29.

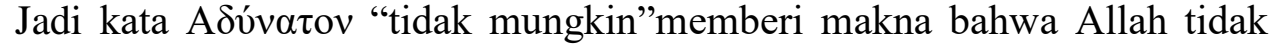
akan memperbaharui orang yang murtad, yang telah mengetahui akan kebenaran namun dengan sengaja menolak keselamatan yang diberikan oleh Kristus karena sesungguhnya Kristuslah jalan keselamatan yang sempurna itu. Orang yang murtad menolak satu-satunya dasar untuk menerima pertobatan. Mereka telah menutup jalan keluar bagi keselamatan yang diberikan Allah dan olehnya Allah sendiri tidak memberi kemungkinan lagi kepada mereka untuk bertobat.

Kemurtadan sama saja dengan "menyalibkan lagi Anak Allah dan menghina-Nya di depan umum." Inilah alasan mengapa Allah tidak mungkin memperbaharui sekali lagi hingga bertobat. Kata kaì "dan" menunjukan adanya

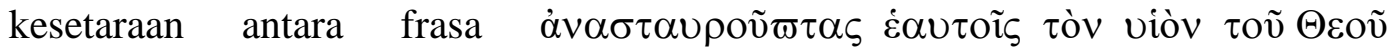
"menyalibkan lagi Anak Allah" dengan frasa $\pi \alpha \rho \alpha \delta \varepsilon \gamma \mu \alpha \tau i \zeta o v \tau \alpha \varsigma$ "menghina-Nya di muka umum". Jika diperhatikan kata $\dot{\alpha} v \alpha \sigma \tau \alpha u \rho o \tilde{\varpi} \tau \alpha \varsigma$ (dari akar kataơv $\alpha \sigma \tau \alpha \cup \rho o ́ \omega)$ "menyalibkan” dan kata $\pi \alpha \rho \alpha \delta \varepsilon \gamma \mu \alpha \tau i \zeta \zeta o v \tau \alpha \varsigma$ (dari akar kata $\pi \alpha \rho \alpha \delta \varepsilon \gamma \mu \alpha \tau i \zeta(\omega)$ "menghina" merupakan dua kata kerja dalam bentuk presentparticiple-active-accusative-masculine-plural (Mounce 2011). Hal ini menunjukan bahwa mereka yang telah menyaksikan penyaliban Yesus namun 
BONAFIDE: Jurnal Teologi dan Pendidikan Kristen

www.jurnal.sttissiau.ac.id/Volume 1/Nomor 2/Desember 2020/hal. 234-257

murtad lagi sama saja dengan menyalibkan Yesus sekali lagi dan itu merupakan sebuah penghinaan besar bagi-Nya.

Orang-orang murtad menyetujui apa yang dilakukan orang Yahudi dalam menyalibkan Kristus dan mereka dengan senang hati akan melakukan lagi hal yang sama jika mereka dapat melakukannya. Mereka menumpahkan penghinaan besar ke atas anak Allah dan kepada Allah sendiri yang mengharapkan semua orang menghormati dan menghargai Anak seperti menghargai dan menghormati Bapa. Frasa "menyalibkan lagi Anak Allah" yaitu penulis surat Ibrani melihat salib sebagai suatu kejadian yang membuka jendela ke dalam hati Allah di mana salib adalah tanda kasih dan pengampunan Allah bagi dosa manusia (Morris 2006).

Frasa "menyalibkan lagi Anak Allah dan menghina-Nya di muka umum" dalam konteks ini jika seseorang yang sudah Kristen tetapi kembali lagi kepada ikatan hukum taurat dan tradisi Yahudi maka orang tersebut tidak mengakui sepenuhnya akan karya keselamatan yang dilakukan Allah di dalam Yesus sebagai penggenapan dari hukum taurat. Mereka kembali menyangkali salib dan ini merupakan sebuah penghinaan besar terhadap Kristus dan karya keselamatan-Nya (Porter 2007). Hal ini sejajar dengan menolak Yesus.

Pada teks ayat 7-8 merupakan sebuah penggambaran kehidupan orangorang yang hidup dalam Kristus dan kehidupan orang-orang yang tidak hidup dalam Kristus yang digambarkan melalui tanah yang menghasilkan tumbuhtumbuhan dan tanah yang menghasilkan semak duri dan rumput duri. Hal ini pun 
BONAFIDE: Jurnal Teologi dan Pendidikan Kristen

www.jurnal.sttissiau.ac.id/Volume 1/Nomor 2/Desember 2020/hal. 234-257

memiliki keterkaitan dengan Kejadian 3:17-18 dan perumpamaan yang dikatakan Yesus dalam Matius 13:24-30 ; 36-43 atau pun dalam Yohanes 15:5-6. Jika

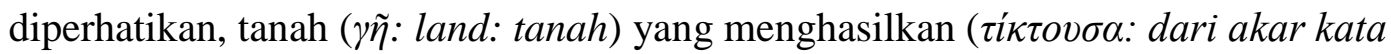

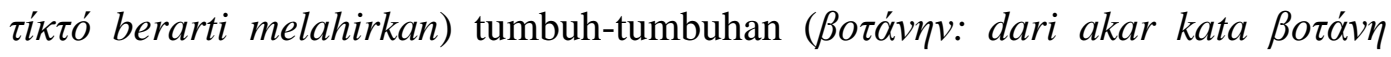
yang berarti tumbuh-tumbuhan) mengindikasikan akan kehidupan orang yang hidup dalam Kristus. Kalimat tanah itu menghisap air hujan ke atasnya dan yang menghasilkan tumbuh-tumbuhan maksudnya adalah orang Kristen yang mengecap firman Allah diberkati dengan pertambahan berkat yang akhirnya memperoleh kemuliaan (Henry 2016). Orang Kristen yang hidup bertekun melakukan firman Allah, merekalah orang-orang yang diberkati yang menghasilkan buah yang baik (tumbuh-tumbuhan) serta mendapat berkat keselamatan dari Allah. Menghasilkan buah adalah bukti hubungan yang benar dengan Kristus karena buahnya adalah buktinya, bukan caranya. Sulit membedakan orang percaya sesungguhnya dan orang yang menyatakan iman yang palsu, karena orang yang tidak percaya dapat berlaku seperti orang percaya. Oleh sebab itu dari buahnyalah dapat membedakannya. Maksud dari ayat ini ialah menggambarkan kehidupan orangorang percaya bagaikan tanah yang menghasilkan tumbuh-tumbuhan artinya mereka yang tetap bertekun hidup dalam firman Allah menghasilkan hidup yang berguna yang pada akhirnya kepada mereka diberi berkat keselamatan (kehidupan kekal) (Erickson 1999). Ini bisa jadi gambaran atau ciri-ciri orang-orang yang digolongkan sebagai orang-orang pilihan Allah yang sesungguhnya tidak dapat

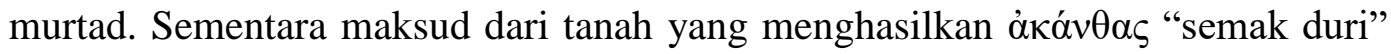


BONAFIDE: Jurnal Teologi dan Pendidikan Kristen

www.jurnal.sttissiau.ac.id/Volume 1/Nomor 2/Desember 2020/hal. 234-257

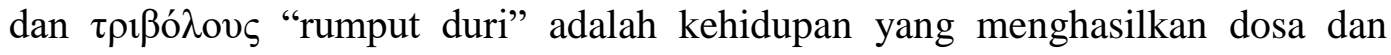
kefasikan yang mengganggu dan menyakiti orang sekelilingnya bahkan menyakiti

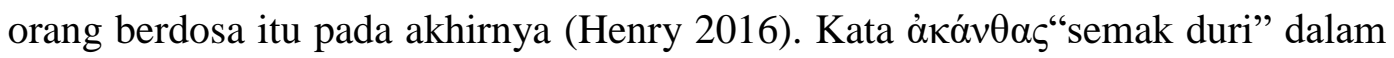
ayat ini memiliki makna yang sama dengan lalang (Mat.13:40) dan ranting kering (Yoh.15:6) yang semuanya tidak berguna dan dicampakan ke dalam perapian. Kehidupan seseorang yang murtad digambarkan seperti ladang atau tanah yang menghasilkan semak atau rumput duri sekalipun tanah tersebut menerima curahan hujan yang memadai dan diolah sedemikian rupa karena diharapkan dapat memberikan hasil yang memuaskan (Erickson 1999). Jadi semak duri atau rumput duri dari ayat ini dapat diartikan sebagai buah dari kehidupan orang yang jauh dari Tuhan. Semak duri dan rumput duri tidak berguna dan tidak menghasilkan apaapa hanya mengundang kutuk dan berakhir pada pembakaran. Akibat dari orang yang murtad adalah orang yang kehilangan berkat Allah dan mengalami penghukuman dan kesengsaraan. Itulah akhir yang mengenaskan dari kemurtadan. Hal ini sama dengan arti menolak Yesus di mana orang yang menolak Yesus sama saja menolak berkat keselamatan yang diberikan Allah karenanya bagi mereka tidak ada lagi pembaruan, yang ada hanyalah penghukuman dan kebinasaan (Macleod 1998).

\section{KESIMPULAN}

Konteks Ibrani 6:1-8 dalam hasil riset tidak menunjukkan adanya proses terjadinya murtad bagi orang Kristen yang sungguh-sungguh percaya Tuhan, sebab orang demikian dipastikan tetap kokoh mempertahankan iman walaupun 
BONAFIDE: Jurnal Teologi dan Pendidikan Kristen

www.jurnal.sttissiau.ac.id/Volume 1/Nomor 2/Desember 2020/hal. 234-257

harus menghadapi penderitaan penganiayaan. Untuk itu, penulis surat Ibrani memberi penegasan pada ayat 1-3 supaya orang percaya harus memiliki fondasi iman yang kuat, karena fakta yang sedang dihadapi dalam konteks ini adalah penganiayaan dari Kaisar Nero yang membuat banyak orang percaya meninggalkan imannya kepada Kristus. Ayat 4 dan 5 memang memperlihatkan peristiwa yang terjadi pada orang Kristen, namun konteks memperlihatkan bahwa tidak semua orang percaya yang pernah diterangi, pernah mengecap dan mendapat bagian dalam Roh Kudus adalah sungguh-sungguh memiliki fondasi iman yang kuat sehingga ada diantara orang percaya tersebut ketika diperhadapkan pada penganiayaan zaman itu meninggalkan imannya kepada Kristus.

Situasi konteks demikian maka, penulis surat Ibrani memberi peringatan

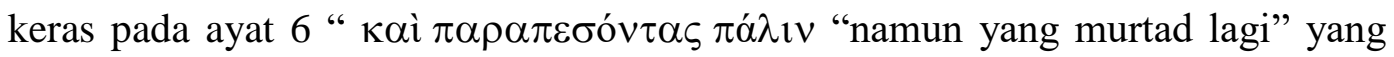
memang mengacu kepada pengertian jatuh ke dalam dosa dengan menolak Kristus. Tetapi orang yang menolak Kristus tersebut dalam situasi konteks ini banyak di antara mereka yang belum memiliki fondasi iman yang kuat atau tidak lahir baru di dalam Kristus sehingga dengan mudah meninggalkan imannya. Untuk itu, semua orang percaya harus sungguh-sungguh percaya supaya kalaupun menghadapi penganiyaan atau penderitaan pasti tidak meninggalkan Kristus kecuali orang Kristen yang tidak lahir baru. Penekanan ini sekaligus menepis pandangan terhadap konteks ini bahwa orang Kristen yang sungguh-sungguh percaya masih bisa menolak Kristus. Hal ini semakin jelas terlihat dalam ayat 7 dan 8 sebagai gambaran orang percaya yang sungguh-sungguh yang tetap 
BONAFIDE: Jurnal Teologi dan Pendidikan Kristen

www.jurnal.sttissiau.ac.id/Volume 1/Nomor 2/Desember 2020/hal. 234-257

bertahan dalam segala situasi yang sulit termasuk terancamnya jiwa, dan gambaran orang yang tidak sungguh-sungguh percaya Kristus pasti dengan mudah menyangkal Kristus. Orang yang demikian pasti tidak akan dibaharui lagi karena dia menolak Kristus selamanya.

\section{DAFTAR PUSTAKA}

Barclay, William. 2011. Pemahaman Alkitab Setiap Hari Surat Ibrani. Jakarta: BPK Gunung Mulia.

Calvin, John. 1853. Commentary On Hebrews,. Grand Rapids: MI: Christian Classics Ethereal Library.

Darmaputera, Eka. 2014. Imamat Yang Sempurna. Jakarta: BPK Gunung Mulia.

Drewes, B. F. dkk. 2006. Kunci Bahasa Yunani Perjanjian Baru Surat RomaKitab Wahyu. Jakarta: BPK Gunung Mulia.

Erickson, Millard J. 1999. Teologi Kristen Vol 1. Malang: Gandum Mas.

Evans, Craig A. 2000. Dictionary of New Testament Backgroung. England: InterVarsity Press.

Henry, Metthew. 2016. Tafsiran Ibrani - Wahyu. Surabaya: Momentum.

Junimen, Jenus. 2012. Dapatkah Keselamatan Orang Percaya Hilang? Yogyakarta: ANDI.

Kawangung, Yudhi, Nelci Nafalia Ndolu, Munatar Kause, Sekolah Tinggi, Agama Kristen, Teruna Bhakti, dan Nusa Tenggara Timur. 2020. "Reinterpretasi Mazmur 23 sebagai Teks Quantum Affirmasi Healing." Kurios 6 (2): 10-20.

Macleod, Donald. 1998. The person of Christ. InterVarsity Press.

Morris, Leon. 2006. Teologi Perjanjian Baru. Malang: Gandum Mas.

Mounce, William D. 2011. Basic Of Biblical Greek: Dasar-dasar Bahasa Yunani Biblika. Malang: Literatur SAAT.

Ndolu, N.N., dan E. Tari. 2020. "Religious Tolerance Based on Ezra 5-6." Biblical Theology Bulletin $50 \quad$ (2): 77-82. https://doi.org/10.1177/0146107920913792.

Newman, Barclay M. 2011. Kamus Yunani-Indonesis untuk Perjanjian Baru. Jakarta: BPK Gunung Mulia.

Palmer, Edwin H. 2013. Lima Pokok Calvinisme. Surabaya: Momentum. 
BONAFIDE: Jurnal Teologi dan Pendidikan Kristen

www.jurnal.sttissiau.ac.id/Volume 1/Nomor 2/Desember 2020/hal. 234-257

Pfeiffer, Charles F., dan Everett F. Harrison, ed. 2013. Tafsiran Alkitab Masa Kini. Malang: Gandum Mas.

Porter, Stanley E. 2007. The Messiah in the Old and New Testamen. Grand Rapids: B.E. Eerdmand Publishing.

Situmorang, Jonar T. H. 2015. Soteriologi (Doktrin Keselamatan). Yogyakarta: ANDI Offset.

Sproul, R. C. 2000. Kaum Pilihan Allah. Malang: Literatur SAAT.

Stedman, Ray C. 1992. Hebrews The New Testament Commentary Series. England: InterVarsity Press.

Stibbs, A. M. 2012. Tafsiran Alkitab Masa Kini 3. Jakarta: Yayasan Komunikasi Bina Kasih.

Stone, Michael E. 2011. Ancient Judaism New Visions and Views. Grand Rapids: B.E. Eerdmand Publishing.

Tim Penyusun. 2012. Tafsiran Alkitab Masa Kini 3. Jakarta: Yayasan Komunikasi Bina Kasih.

Tubagus, Steven. 2019. "Metode-Metode Yang Kreatif Dan Efektif Untuk Pencapaian Tujuan Pendidikan Agama Kristen.” Tumou Tou , Juli, 103-16.

- 2020. "Makna Kepemimpinan Daud dalam Perjanjian Lama." Kinaa: Jurnal Kepemimpinan Kristen dan Pemberdayaan Jemaat 1 (1): 56-67. 